\section{Validity and reproducibility of a food frequency questionnaire to assess food group intake in adolescents}

\author{
Validade e reprodutibilidade de um questionário \\ de frequência alimentar baseado nos grupos \\ alimentares para adolescentes
}

\section{Validez y reproducibilidad de un cuestionario de frecuencia alimentaria sobre la base de grupos de alimentos para los adolescentes}

Marcelle Flores Martinez ${ }^{1}$

Sonia Tucunduva Philippi 1

Camilla Estima 1

Greisse Leal 1

\footnotetext{
${ }^{1}$ Faculdade de Saúde Pública, Universidade de São Paulo, São Paulo, Brasil.

Correspondence M. F. Martinez Faculdade de Saúde Pública Universidade de São Paulo. Rua Madre Rita Amada de Jesus 72, apto. 111A, São Paulo, SP 04721-050, Brasil. marcellefmartinez@gmail.com
}

\begin{abstract}
The objective of this study was to assess the validity and reproducibility of a food frequency questionnaire to assess intake of the food groups included in the food guide pyramid for adolescents (FFQ-FP). The final version of the FFQ-FP consisted of 50 food items. The study was carried out with a sample of 109 adolescents over a period of four months. A $24 \mathrm{hr}$ recall (24hr) was conducted four times and the FFQ-FP was conducted twice. Validity was determined by comparing the second FFQ-FP and the mean of the four 24hrs, while reproducibility was verified by comparing the results of the two FFQ-FPs. Statistical analysis was carried out using medians, standard deviations, Pearson and intraclass correlations and Kappa statistics to assess concordance. Best results were achieved for the rice (including bread, grains and starches), meats and sugars groups. Weakest correlation was observed for the variable vitamin $C$. The validity and reproducibility of the FFQ-FP was satisfactory for most variables.
\end{abstract}

Eating; Adolescent; Reproducibility of Results

\section{Resumo}

O objetivo foi verificar a validade e reprodutibilidade de um questionário de frequência alimentar baseado nos grupos alimentares da pirâmide alimentar para adolescentes (QFA-PA). Após a identificação dos alimentos a serem incluídos no QFA-PA, a versão final consistiu em 50 itens. O estudo foi realizado com 109 adolescentes durante um período de quatro meses. Foram aplicados quatro recordatórios de $24 h$ (R24h) e dois QFA-PA. A validade foi obtida pela comparação entre o segundo QFA-PA e a média dos R24h, enquanto que a reprodutibilidade foi mensurada por meio da comparação dos dois QFA-PA. As análises estatísticas foram realizadas utilizando-se médias, desvios-padrão, correlações de Pearson, e intraclasse e concordância. As variáveis melhor avaliadas foram os grupos do arroz, pão, massa, batata e mandioca, das carnes e de açúcares e doces. Os piores resultados foram observados para a vitamina C. O QFA-PA apresentou validade satisfatória e reprodutibilidade aceitável para a maioria das variáveis.

Ingestão de Alimentos; Adolescente; Reprodutibilidade dos Testes 


\section{Introduction}

Food frequency questionnaires (FFQ) are widely used in epidemiological studies to evaluate the relationship between diet and disease. Apart from having a high degree of validity and reproducibility and being practical and easy to use, this cost-effective method simplifies data analysis, does not influence food intake patterns and minimizes intrapersonal variation. FFQs include a list of foods (which may vary according to the study objectives or the foods commonly consumed by the study population) and options of frequency of consumption. The development of efficient validated tools to assess food consumption among adolescents is fundamental to discovering the association between food intake and noncommunicable chronic diseases 1,2 .

In light of the above, the objective of this study was to assess the validity and reproducibility of a food frequency questionnaire to assess intake of the food groups included in the food guide pyramid adapted for adolescents (FFQ-FP).

\section{Materials and methods}

This cross-sectional study was a part of a larger project called Eating Attitudes and their Determinants among Adolescents in the City of São Paulo. The study population consisted of 109 adolescents from three randomly selected classes in the Parque da Juventude School, which was randomly selected from 12 technical schools participating in the above project. Only individuals aged between 15 years and 19 years and 11 months, who had completed at least three 24hour recalls (24hR) and one FFQ, and who had signed an informed consent form were included in the study.

\section{Development of the FFQ-FP}

A database that provides information about food consumption by the adolescents $3,4,5$ was created to develop the FFQ. The reported foods were grouped according to the physical characteristics and nutrient profile of relatively homogeneous food items.

Eating habits were characterized by compiling a list of frequently reported and absent items included in the FFQ-FP (alcoholic beverage, soy beverage, flavored milk in cartons, fermented milk beverages, candy, bubblegum, popsicles, cereal, instant noodles, chicken nuggets, cream cheese, yogurt and sweets) that made up at least $90 \%$ of energy and macronutrient and micronutrient intake (cholesterol, calcium and iron) and a list of frequently reported items that do not provide additional energy input (water, tea/ coffee, greens and vegetables). Consumption of the foods that qualified for inclusion in the FFQFP was classified into the following frequency categories previously adopted by Colcucci 6 : at least twice a day; once a day; twice to four times a week; once a week; once to three times a month; less than once a month; and never. Portion sizes were not assessed to ensure a more realistic characterization of eating habits 1 .

The FFQ-FP adopted the standard units of measurement of the food groups used in the food guide pyramid adapted for adolescents 4 . The food items were organized in the pyramid in the following respective food groups: rice (rice, bread, crackers, pasta and cake without filling), greens (greens and vegetables), fruit (fruit), milk (milk, cheeses, cream cheese and yogurt), meat (beef, chicken, fish, pork, egg), beans (beans), sugar (sugar, milk powder, sweets) and oils (margarine or butter, mayonnaise, olive oil/oil).

The reference period for reporting habitual food intake was the 12 months prior to filling out the questionnaire.

\section{Reference method and data collection}

The reference method used by this study to assess the validity and reproducibility of the FFQ-FP was the self-completed $24 \mathrm{hR} 7$. Data was collected between March and June 2010 using four $24 \mathrm{hR}$ and two FFQ-FPs (FFQ-FP1 and FFQ-FP2) conducted at 30-day and 90-day intervals, respectively.

Validity was assessed by comparing the results of the FFQ-FP2 with the mean of the four $24 \mathrm{hR}$, while reproducibility was evaluated by comparing the results of the two FFQ-FPs.

\section{Data processing}

Consumption of the food items included in the $24 \mathrm{hR}$ was converted into the units of measurement used in the Virtual Nutri Plus software (University of São Paulo, São Paulo, Brazil). Frequency of consumption based on the abovementioned categories was converted into daily equivalent frequency of consumption.

Daily intake by pyramid food group was calculated by dividing the number of servings consumed (based on frequency of intake) by the number of servings recommended by the food guide pyramid adapted for adolescents 4,5 and multiplying the result by the daily frequency of consumption.

Total serving intake by food group was the sum of the total number of servings consumed of each food item. 


\section{Statistical analysis}

Mean and standard deviation (SD) of energy and nutrient consumption and serving intake were calculated using Microsoft Excel 2007 (Microsoft Corp., USA) and SPSS v.12.0 (SPSS Inc., Chicago, USA). The significance level was set at $5 \%$ $(\mathrm{p} \leq 0.05)$.

The Kolmogorov-Smirnov test was used to test for normal distribution. Variables with asymmetric distributions were transformed into their natural logarithms. A variance ratio test was carried out to correct for intrapersonal and interpersonal variation using the following equation:

$$
r_{v}=r_{o}(1+\lambda / n) 1 / 2
$$

where $r_{v}=$ true correlation, $r_{0}=$ observed correlation between the FFQ-FP2 and $24 \mathrm{hR}$ average, $\lambda=$ ratio of intrapersonal and interpersonal variation from the $24 \mathrm{hR}, \mathrm{n}=$ number of replicates (in this case four recalls).

The variables were energy-adjusted using the method of residues described by Willet \& Stampfer 8 in order to control for confounding factors caused by total consumption of energy and remove external variations 1 .

\section{Validation and reproducibility}

Differences between means were analyzed using a paired Student's t-test. Crude, deattenuated and energy-adjusted deattenuated Pearson correlation coefficients (PCC) were used to evaluate whether the FFQ-FP was effective for classifying individuals by intake levels. Crude, deattenuated and energy-adjusted deattenuated intraclass correlation coefficients (ICC) were used to test for the degree of agreement between the tools. Acceptable correlation values varied between 0.40 and 0.701 .

Consumption was categorized into tertiles to observe the proportion of individuals classified in same and opposite tertiles. Kappa statistics were used to evaluate concordance between surveys.

\section{Ethical issues}

This study was approved by the Research Ethics Committee of the University of São Paulo (number 133/2009).

\section{Results}

The study was carried out with a sample of 109 adolescents, of which 60 (55\%) were boys. The mean age of the sample was 16 years $(\mathrm{SD}=0.99)$.
Validity

Compared with the $24 \mathrm{hR}$ method, the FFQ-FP2 underestimated the intake of energy, water, saturated fat, protein, cholesterol, vitamins $\mathrm{A}, \mathrm{C}$ and $\mathrm{D}$, phosphorus and iron, and consumption in the rice (bread, pasta, potato, manioc, etc.) and meat (including eggs) groups (Table 1).

Energy-adjusted deattenuated PCCs were high for the rice (0.88), fruit $(0.77)$, meat $(0.82)$ and sugars (0.82) groups, and acceptable for water, the other pyramid food groups, and all macro and micronutrients ( 0.41 to 0.7 ), except polyunsaturated fat, total fiber and vitamins $\mathrm{C}, \mathrm{D}$ and E (0.13-0.37). There was an increase in the coefficient values of the following groups and items after adjustment for energy intake: rice, fruits, beans, sugars, fats (except for saturated fats), cholesterol, vitamins D and E, phosphorus and iron (Table 2).

ICC values were similar to PCC values for crude data (except for vitamin A and iron), deattenuated data (except for vitamin A and iron) and energy-adjusted deattenuated data (except for water, the fruit and beans groups, total fat and vitamin D) (Table 2).

The proportion of individuals classified in the same tertile by the $24 \mathrm{hR}$ and FFQ-FP2 varied from $43.5 \%$ (polyunsaturated fat and vitamin D) to $71.3 \%$ (sugars). The degree of concordance between the two tools was $54.5 \%$, and $13 \%$ of the adolescents were classified in opposite tertiles. Kappa values varied between 0.15 (polyunsaturated fat) and 0.57 (sugars) (Table 2).

\section{Reproducibility}

The results for mean energy, nutrient and servings intake from the two FFQ-FP tests are presented in Table 1; most of the values for nutrients were lower in the retest. Statistically significant differences between the FFQ-FP1 and the FFQFP2 were observed for carbohydrates.

Energy intake had an intermethod PCC of 0.55 , while the mean value for all variables was 0.50 . After adjustment for energy intake, values increased in the sugars group (0.74) (Table 3). Energy intake had an ICC of 0.53 , while the mean values for crude and adjusted data were 0.55 and 0.50 , respectively. Values for crude data were high in the rice, sugars (0.71) and meat groups (0.77). After adjustment for energy intake, values increased slightlyin the sugars group (0.72) (Table 3 )

The proportion of individuals classified in the same tertile by the two FFQ-FPs varied between $41.6 \%$ (monounsaturated fat intake) and $65.7 \%$ (sugars group). Mean concordance was $51.4 \%$ and $14 \%$ of the adolescents were classified 
Mean (SD) of the variables energy, water, food groups and nutrients of the four 24-hour recalls (24hR) and two food frequency questionnaires (FFQ-AP) based on food groups included in the food guide pyramid adapted for adolescents (energy-adjusted and deattenuated). Parque da Juventude Technical School, São Paulo, Brazil, 2011.

\begin{tabular}{|c|c|c|c|c|c|}
\hline \multirow[b]{2}{*}{ Energy } & \multirow{2}{*}{$\begin{array}{c}24 \mathrm{hR} \text { * } \\
\text { Mean (SD) } \\
2,707.6(587.8)\end{array}$} & \multirow{2}{*}{$\begin{array}{c}\text { FFQ-AP1 } \\
\text { Mean (SD) } \\
2,765.30(1,179.7)\end{array}$} & \multirow{2}{*}{$\begin{array}{c}\text { FFQ-AP2 } \\
\text { Mean (SD) } \\
2,493.50(847.6)\end{array}$} & \multicolumn{2}{|c|}{$\begin{array}{c}\text { 24hRxFFQ2 and } \\
\text { FFQ1xFFQ2 } \\
\text { p-value }\end{array}$} \\
\hline & & & & 0.002 & 0.062 \\
\hline Water & $0.49(0.2)$ & $0.45(0.3)$ & $0.45(0.4)$ & 0.121 & 0.820 \\
\hline \multicolumn{6}{|l|}{ Food groups } \\
\hline Rice group & $5.28(1.8)$ & $4.81(2.3)$ & $4.96(2.3)$ & 0.003 & 0.423 \\
\hline Greens group & $0.65(0.5)$ & $0.74(0.9)$ & $0.70(0.7)$ & 0.937 & 0.445 \\
\hline Fruit group & $0.83(0.5)$ & $0.73(1.1)$ & $0.78(0.8)$ & 0.119 & 0.444 \\
\hline Milk group & $1.73(0.8)$ & $2.26(1.2)$ & $2.16(1.2)$ & 0.000 & 0.276 \\
\hline Meat group & $2.97(1.6)$ & $2.40(1.5)$ & $2.61(1.6)$ & 0.000 & 0.068 \\
\hline Beans group & $1.41(0.7)$ & $1.54(1.1)$ & $1.80(1.2)$ & 0.000 & 0.032 \\
\hline Sugars group & $5.59(1.8)$ & $6.35(3.5)$ & $6.34(3.3)$ & 0.000 & 0.874 \\
\hline Oils group & $1.98(0.9)$ & $2.15(1.5)$ & $2.25(1.5)$ & 0.051 & 0.560 \\
\hline \multicolumn{6}{|l|}{ Nutrients } \\
\hline Carbohydrate (g) & $314.39(79.4)$ & $339.92(90.3)$ & 308.09 (113.4) & 0.558 & 0.001 \\
\hline Total fat (g) & $99.43(19.3)$ & 97.37 (29.9) & $97.24(36.2)$ & 0.488 & 0.962 \\
\hline Polyunsaturated fatty acids (g) & $14.37(5.2)$ & $13.18(5.0)$ & $13.06(7.2)$ & 0.071 & 0.951 \\
\hline Monounsaturated fatty acids (g) & $22.64(10.9)$ & $22.03(8.8)$ & $21.88(11.7)$ & 0.463 & 0.862 \\
\hline Saturated fatty acids (g) & $28.36(10.9)$ & $23.64(9.3)$ & $23.46(11.5)$ & 0.000 & 0.811 \\
\hline Proteins (g) & 98.66 (41.9) & $89.76(32.1)$ & $87.28(35.7)$ & 0.001 & 0.419 \\
\hline Dietary fiber (g) & $15.14(5.8)$ & $13.98(6.2)$ & $14.32(6.9)$ & 0.272 & 0.427 \\
\hline Cholesterol (g) & $279.11(121.2)$ & $220.70(108.3)$ & 224.98 (169.3) & 0.001 & 0.666 \\
\hline Vitamin A (UI) & $660.50(373.7)$ & $500.94(306.1)$ & $491.74(267.1)$ & 0.000 & 0.876 \\
\hline Vitamin C (mg) & 79.59 (33.3) & 58.59 (32.6) & $54.21(27.7)$ & 0.000 & 0.326 \\
\hline Thiamin (mg) & $1.74(0.8)$ & $2.48(1.1)$ & $2.26(1.0)$ & 0.583 & 0.583 \\
\hline Vitamin D (mg) & $6.49(14.2)$ & $1.10(0.6)$ & $1.35(0.9)$ & 0.000 & 0.001 \\
\hline Niacin (mg) & $24.34(8.4)$ & $25.45(9.5)$ & $24.24(10.5)$ & 0.828 & 0.273 \\
\hline Vitamin E (mg) & $19.60(5.8)$ & $21.22(7.9)$ & 22.37 (11.3) & 0.010 & 0.168 \\
\hline Calcium (mg) & $786.50(304.6)$ & $929.76(422.7)$ & 868.49 (342.8) & 0.010 & 0.107 \\
\hline Zinc (mg) & $11.25(6.2)$ & $10.68(4.9)$ & $9.98(4.7)$ & 0.010 & 0.162 \\
\hline Phosphorus (mg) & $884.78(390.2)$ & $795.62(277.5)$ & 778.28 (333.5) & 0.002 & 0.553 \\
\hline Iron (mg) & $22.91(24.1)$ & $14.57(5.0)$ & $13.88(5.3)$ & 0.000 & 0.198 \\
\hline Selenium (mg) & $81.98(36.8)$ & $88.13(38.5)$ & 84.89 (43.4) & 0.480 & 0.416 \\
\hline
\end{tabular}

* Deattenuated values.

in opposite tertiles. Kappa values varied between 0.13 (monounsaturated fat intake) and 0.51 (sugars group) (Table 3$)$.

\section{Discussion}

Currently several options exist for assessing food intake and one the most commonly used tools are FFQs. However, there are only a limited num- ber of options of validated tools for assessing food intake in adolescents $1,9,10$.

The ideal tool should be brief, easy to administer, low-cost and provide useful information. However, specific characteristics of adolescents should be taken into account when designing FFQs, including variations in cognitive abilities, such as memory and their limited knowledge of foods and food preparation, and difficulties in estimating the size of servings 10 . Despite this, 
Correlation coefficients, percentage of adolescents classified in tertiles, weighted kappa, energy-adjusted deattenuated concordance of validity. Parque da Juventude Technical School, São Paulo, Brazil, 2011.

\begin{tabular}{|c|c|c|c|c|c|c|c|c|c|c|}
\hline & \multicolumn{10}{|c|}{ Validity (average 24R x FFQ-AP2) } \\
\hline & \multicolumn{2}{|c|}{ Crude } & \multicolumn{2}{|c|}{ De-attenuated } & \multicolumn{2}{|c|}{$\begin{array}{l}\text { Energy-adjusted } \\
\text { de-attenuated }\end{array}$} & \multirow[t]{2}{*}{$\begin{array}{c}\text { Concor- } \\
\text { dance (\%) }\end{array}$} & \multirow[t]{2}{*}{$\begin{array}{c}\text { Opposite } \\
\text { tertiles (\%) }\end{array}$} & \multirow[t]{2}{*}{ Kappa } & \multirow[t]{2}{*}{$\mathrm{p}$-value } \\
\hline & Pearson & Intraclass & Pearson & Intraclass & Pearson & Intraclass & & & & \\
\hline Energy & 0.51 & 0.51 & - & - & - & - & 60.0 & 9.5 & 0.50 & $<0.001$ \\
\hline Water & 0.43 & 0.43 & 0.44 & 0.44 & 0.42 & 0.38 & 53.3 & 13.0 & 0.29 & $<0.001$ \\
\hline \multicolumn{11}{|l|}{ Food groups } \\
\hline Rice group & 0.81 & 0.80 & 0.82 & 0.81 & 0.88 & 0.86 & 67.6 & 6.0 & 0.51 & $<0.001$ \\
\hline Greens group & 0.68 & 0.67 & 0.69 & 0.70 & 0.64 & 0.58 & 55.3 & 12.0 & 0.33 & $<0.001$ \\
\hline Fruit group & 0.76 & 0.76 & 0.77 & 0.78 & 0.77 & 0.69 & 64.3 & 9.0 & 0.46 & $<0.001$ \\
\hline Milk group & 0.67 & 0.67 & 0.68 & 0.70 & 0.66 & 0.60 & 58.3 & 12.0 & 0.38 & $<0.001$ \\
\hline Meat group & 0.84 & 0.84 & 0.85 & 0.85 & 0.82 & 0.82 & 63.0 & 9.3 & 0.47 & $<0.001$ \\
\hline Sugars & 0.82 & 0.80 & 0.83 & 0.81 & 0.84 & 0.70 & 71.3 & 8.0 & 0.57 & $<0.001$ \\
\hline Oils & 0.46 & 0.45 & 0.47 & 0.46 & 0.44 & 0.40 & 53.7 & 13.0 & 0.31 & $<0.001$ \\
\hline \multicolumn{11}{|l|}{ Nutrients } \\
\hline Carbohydrate (g) & 0.48 & 0.48 & 0.50 & 0.49 & 0.50 & 0.47 & 60.2 & 12.0 & 0.40 & $<0.001$ \\
\hline Total fat (g) & 0.38 & 0.39 & 0.39 & 0.40 & 0.41 & 0.34 & 54.6 & 13.0 & 0.32 & $<0.001$ \\
\hline Polyunsaturated fatty acids (g) & 0.21 & 0.21 & 0.22 & 0.23 & 0.29 & 0.27 & 43.5 & 17.0 & 0.15 & 0.025 \\
\hline Monounsaturated fatty acids (g) & 0.40 & 0.41 & 0.41 & 0.42 & 0.44 & 0.44 & 47.2 & 16.0 & 0.21 & 0.002 \\
\hline Saturated fatty acids (g) & 0.43 & 0.43 & 0.44 & 0.44 & 0.43 & 0.43 & 45.4 & 13.0 & 0.18 & 0.008 \\
\hline Proteins (g) & 0.59 & 0.57 & 0.60 & 0.58 & 0.57 & 0.57 & 50.9 & 14.0 & 0.26 & 0.264 \\
\hline Dietary fiber (g) & 0.37 & 0.37 & 0.38 & 0.38 & 0.37 & 0.37 & 55.5 & 12.0 & 0.33 & $<0.001$ \\
\hline Cholesterol (g) & 0.40 & 0.38 & 0.41 & 0.39 & 0.44 & 0.42 & 54.7 & 13.0 & 0.32 & $<0.001$ \\
\hline Vitamin A (UI) & 0.54 & 0.38 & 0.58 & 0.40 & 0.47 & 0.45 & 53.7 & 14.0 & 0.31 & $<0.001$ \\
\hline Vitamin C (mg) & 0.27 & 0.22 & 0.29 & 0.23 & 0.27 & 0.26 & 44.4 & 14.0 & 0.17 & 0.014 \\
\hline Vitamin D (mg) & 0.01 & 0.01 & 0.03 & 0.05 & 0.13 & 0.02 & 43.5 & 15.0 & 0.15 & 0.025 \\
\hline Niacin (mg) & 0.55 & 0.55 & 0.57 & 0.58 & 0.53 & 0.52 & 49.1 & 17.0 & 0.24 & 0.001 \\
\hline Vitamin E (mg) & 0.26 & 0.25 & 0.27 & 0.27 & 0.31 & 0.26 & 48.2 & 15.0 & 0.22 & 0.001 \\
\hline Calcium (mg) & 0.54 & 0.54 & 0.55 & 0.55 & 0.52 & 0.52 & 52.7 & 14.0 & 0.29 & $<0.001$ \\
\hline Zinc (mg) & 0.58 & 0.54 & 0.60 & 0.55 & 0.58 & 0.55 & 52.8 & 15.0 & 0.29 & 0.001 \\
\hline Phosphorus (mg) & 0.51 & 0.50 & 0.52 & 0.51 & 0.53 & 0.52 & 52.8 & 15.0 & 0.29 & $<0.001$ \\
\hline Iron (mg) & 0.39 & 0.06 & 0.40 & 0.08 & 0.53 & 0.52 & 54.6 & 15.0 & 0.32 & 0.001 \\
\hline Selenium (mg) & 0.51 & 0.51 & 0.52 & 0.52 & 0.52 & 0.51 & 53.7 & 15.0 & 0.31 & $<0.001$ \\
\hline
\end{tabular}

24hR: 24-hour recall; FFQ-AP: food frequency questionnaire based on food groups included in the food guide pyramid adapted for adolescents.

Goodwin et al. ${ }^{11}$ highlight that adolescents aged between 13 and 17 years are able to complete FFQs and provide reliable information without parental help. The method used by this study has a number of characteristics which are essential to a valid adolescent food intake assessment tool: it was developed specifically for adolescents; participants had a relatively high level of education (high school), were motivated to participate in the study and showed interest in learning about nutrition; an adequate sample size (three classrooms, each with 40 students) was used; the FFQ-FP took a maximum of 30 minutes to complete and was therefore not time consuming 11; the FFQ-FP facilitated the dissemination of nutritional guidelines; study participants had prior knowledge of the pyramid design and food groups. 
Correlation coefficients, percentage of adolescents classified in tertiles, weighted kappa, energy-adjusted deattenuated concordance of reproducibility. Parque da Juventude Technical School, São Paulo, Brazil, 2011.

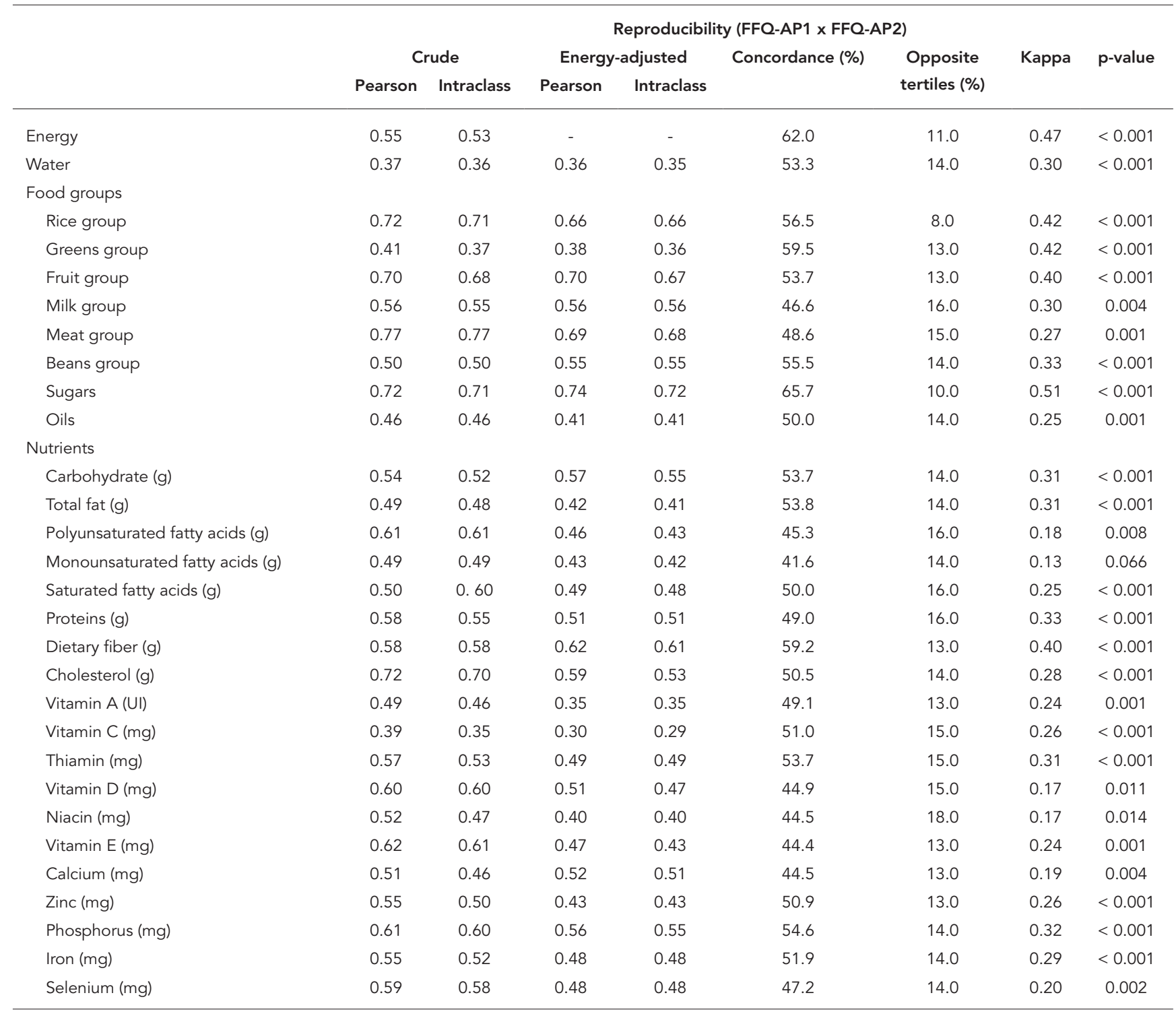

FFQ-AP: food frequency questionnaire based on food groups included in the food guide pyramid adapted for adolescents.

\section{Structure of the FFQ-FP}

The number of food items included in the FFQ can vary widely and Cade et al. 12 identified the use of between five and 350 foods items. However, Egashira et al. 13 suggest that extensive lists may not evaluate food consumption accurately because they lead to fatigue and tedium when filling out the questionnaire.

The FFQ-FP used in this study included 50 food items and this may have exerted enough influence to lower the correlation coefficients. However, it should be noted that the selection of food items was based on previously tested methodologies 1,14 , with emphasis on high energy foods in the case of the $24 \mathrm{hR}$. Although the formulation of the FFQ-FP included the design and use of the food groups of the food guide pyramid 15 , fruit, leafy greens and vegetables were not specified due to the high degree of variety and variability in consumption. 


\section{Validity}

FFQs have the potential to play an important role in the monitoring and evaluation of food intake behavior 16,17. In Brazil, however, studies that assess the validity of FFQs designed to assess food intake among adolescents are scarce.

The selection of an appropriate reference method is an essential element of the effective assessment of FFQs and research in this area is often hampered by the lack of a gold standard for dietary intake 18. Furthermore, error detection methods should be as independent as possible 19,20. The main sources of error in FFQs are participant memory, the interpretation of questions, perception of serving sizes and the limitations imposed by a fixed list of food items. Open-ended diet records do not depend on memory and are likely to result in less correlated errors 1,18 . Nevertheless, keeping a diet record is a substantial burden on participants and often influences the respondent's diet. Thus, multiple $24 \mathrm{hr}$ dietary recalls have been shown to be the most appropriate reference method for use in epidemiological studies designed to validate food intake 21,22 and a review by Cade et al. 12 showed that $75 \%$ of studies assessed FFQ against 24hR.

Due to the high degree of intrapersonal variability associated with this method, it is common to repeat the $24 \mathrm{hR}$ or use larger samples. Adjustments were therefore made to account for intrapersonal variability to minimize error due to correction of the consumption distribution.

Adjustment for energy intake led to lower correlation coefficients for most nutrientsincluded in this study, corroborating the findings of Willett 1 . Increases in correlation coefficients after adjustment may be due to error removal due to the effect of total energy and nutrient consumption 17. Molag et al. 2 observed that energy-adjusted correlation coefficients were $0.02-0.08$ higher for all nutrients, except vitamin C (0.05). In the present study, intermethod correlations were higher after adjustment (0.01-0.16).

Although there was a significant difference in the means of most dietary variables between the different methods, it is important note that correlation values of 23 (82\%) out of the 28 groups analyzed by this study were above 0.40 . These findings are similar to those of Voci et al. 17 and Willet ${ }^{1}$, who stated that correlations must be between 0.4 and 0.7 to be acceptable. Correlations less than 0.30 were observed for polyunsaturated fats, fiber and vitamins C, D and E. Similar results were observed by Marks et al. 21 and Malekshah et al. 22.

FFQ-FP correlation coefficients for fruit, greens and milk groups observed by Millen et al. 23 were higher than those observed by Spencer et al. 24 ( 0.17 and 0.58 , respectively). The results obtained in the present study contradict those from a review of FFQ validation studies carried out by Cade et al. 12 in which mean correlations were generally lower for leafy greens and vegetables due to a number of reasons, including duplicated item counting and social desirability bias.

The results regarding fat intake using the FFQ-FP were unsatisfactory, even after energy adjustment, corroborating the findings of the European Prospective Investigation into Cancer and Nutrition (EPIC) study 25.

The kappa values observed by this study were similar to those found by Hong et al. 26, who reported values ranging from 0.36 to 0.54 for energy, protein and fat, and $0.14,0.19$ and 0.2 for vitamin $\mathrm{C}$, calcium and fiber, respectively, indicating moderate and fair reliability. The values of the present study were lower than those observed by Assis et al. 27 in a study assessing the validity of FFQ for students (kappa values of 0.76 for fruit and 0.71 for leafy greens). In the present study, a mean of $54.5 \%$ of individuals were classified in the same tertile, corroborating the findings of Masson et al. 28. According to the classification used by this study all variables, except fats, vitamins E, D and niacin, presented a concordance rate of over $50 \%$ for individuals classified in the same tertiles.

\section{Reproducibility}

Another important element of FFQ is the reference period for reporting food intake. The replication interval should neither be too short (because subjects may remember their previous responses and simply repeat the answers) nor too long (so as not to influence changes in diet) 29 . This study adopted a three-month interval for the FFQ-FP, which is considered a reasonable period of time. It should also be noted that the time interval can also influence changes in food intake due to seasonality and it is possible that this may have happened in this study, thus leading to lower true correlations, especially for micronutrients 30 .

Cullen et al. 10 and Marchioni et al. 29 found lower retest values, different values between two FFQ applications and significant differences for carbohydrates, which is consistent with the findings of the current study.

The PCC value observed by the present study agrees with the findings of Rockett et al. ${ }^{9}$ who observed values between 0.26 (protein and iron) and 0.58 (calcium).

The crude ICC values of energy, vitamin C and the meats group were $0.53,0.35$ and 0.77 , 
respectively (mean of 0.55), while adjusted values of vitamin $C$ and sugars were 0.29 and 0.72 , respectively (mean of 0.50 ). The values observed by the present study are similar to those found by Speck et al. ${ }^{31}$. Marchioni et al. 29 observed lower adjusted values ( 0.25 fat and 0.58 vitamin $C$ ).

The concordance rate between the two tools was $51.4 \%$ and $14 \%$ of the adolescents were classified in opposite tertiles. Similar results were found by Marchioni et al. 29. Considering the variability of adolescent food intake, Vereecken et al. 32 determined that this rate represents a reasonable level of reproducibility of FFQ for adolescents.

Kappa values above 0.40 were observed for the variables energy, fiber and the rice, greens, fruits and sugars groups. The value for protein was similar to that found by Marchioni et al. 29 (0.33).

It is important to note that this is the first accurate FFQ that evaluates food intake based on the food pyramid developed and validated for adolescents in Brazil. The FFQ-FP represents a new approach to the assessment of dietary intake which is more visually appealing and quicker and easier to fill out and its structure facilitates the classification of individuals according intake levels.

A possible limitation of this study is the fact that the number of $24 \mathrm{hR}$ was insufficient to assess the intake of micronutrients, fiber and fats. Furthermore, certain variables, particularly vitamins, are subject seasonal variations.

Another limitation is that the food list used by this study was based on a study developed in a public school in Ilha Bela, State of São Paulo by Leal ${ }^{3}$. However, this study found mean en- ergy values for boys and girls of 2,600kcal and $2,200 \mathrm{kcal}$, respectively, which is similar to the findings of Albano \& Souza 33 in a study carried out in the city of São Paulo. Similar results were also found with respect to macronutrients, micronutrients and food groups for the two cities. Carbohydrate intake was lower than the recommended intake for adolescents, while protein and lipid intake was higher. The mean intake in the milk group (including cheese and yogurt) was $50 \%$ lower than the recommended intake for this age group 33,34. Intake in the greens and fruit groups was lower than recommended in the food pyramid. This finding is similar to the findings of a study in São Paulo carried out by Toral et al. 35 .

Since this is a pilot study, the differences in eating behavior are not particularly marked. It is important to highlight that the correlations found by the present study are consistent with the literature, indicating that food intake in Ilha Bela can be used as a basis to compose the FFQFP list for the metropolitan region of São Paulo.

\section{Conclusions}

The validity of the FFQ-FP used in this study was satisfactory for all variables except polyunsaturated fats, vitamins $\mathrm{C}, \mathrm{D}$ and E. Reproducibility was also satisfactory for all variables except water, vitamins $\mathrm{A}$ and $\mathrm{C}$ and the greens group. It is hoped that the results of this study contribute to the development of guidelines for nutrition intervention, public policies and further epidemiological studies.

\section{Resumen}

El objetivo fue evaluar la validez y reproducibilidad de un cuestionario de frecuencia de alimentos sobre la base de grupos de alimentos en la pirámide alimenticia para adolescentes (FFQ-AP). Después de identificar los alimentos que se incluyen en el FFQ-AP, la versión final estuvo compuesta por 50 ítems. El estudio se realizó con 109 adolescentes durante un período de cuatro meses. Se realizaron cuatro recordatorios de 24 horas dietéticos (R24h) y dos FFQ-AP. La validez se evaluó mediante la comparación del segundo cuestionario de frecuencia (FFQ-AP) y el promedio de los R24h, mientras que la reproducibilidad se evaluó mediante la comparación de los dos FFQ-AP. Los análisis estadísticos se realizaron con medias, desviaciones estándar y correlaciones de Pearson y correlación intraclase. Los grupos de alimentos con variables evaluadas fueron: arroz, pan, pasta, patatas y yuca, carne y azúcar y dulces. Los peores resultados se observaron con respecto a la vitamina $C$. El FFQ-AP mostró una validez aceptable y de reproducción satisfactoria para la mayoría de las variables.

Ingestión de Alimentos; Adolescente; Reproducibilidad de Resultados 


\section{Contributors}

M. F. Martinez participated in project conception, data analysis and interpretation and drafting of the final version of this article. S. T. Philippi helped orientate this work and contributed to the critical revision of the intellectual content and approval of the final version of this article. C. Estima and G. Leal contributed to project conception, data collection and the critical revision of the text and approval of the final version of this article.

\section{Acknowledgments}

We are grateful to FAPESP for their financial support.

\section{References}

1. Willet WC. Nutritional epidemiology. 2nd Ed. Oxford: Oxford University Press; 1998.

2. Molag M, Vries J, Ocke M, Dagnelie P, van den Brandt PA, Jansen M, et al. Design characteristics of food frequency questionnaires in relation to their validity. Am J Epidemiol 2007; 166:1468-78.

3. Leal GVS. Consumo alimentar, estado nutricional e nível de atividade física de adolescentes do projeto Ilhabela - SP [Dissertação de Mestrado]. São Paulo: Faculdade de Saúde Pública, Universidade de São Paulo; 2008.

4. Philippi ST. Alimentação saudável e a pirâmide dos alimentos. In: Philippi ST, organizadora. Pirâmide dos alimentos: fundamentos básicos da nutrição. Barueri: Edições Manole; 2008. p. 1-29.

5. Leal GVS, Philippi ST, Matsudo SMM, Toassa E. Consumo alimentar e padrão de refeições de adolescentes, São Paulo. Rev Brasil Epidemiol 2010; 13:455-65.

6. Colluci ACA. Desenvolvimento de um questionário de freqüência alimentar para avaliação do consumo alimentar de crianças de 2 a 5 anos de idade [Dissertação de Mestrado]. São Paulo: Faculdade de Saúde Pública, Universidade de São Paulo; 1999.
7. Dunker KLL, Philippi ST. Recordatório alimentar de 24 horas "modificado" - avaliação do consumo alimentar de adolescentes. In: Anais do 1o Congresso Latino-Americano de Nutrição Humana. Porto Alegre: Plenarium Ltda.; 1999. p. 6.

8. Willet WC, Stampfer MJ. Total energy intake: implications for epidemiological analyses. Am J Epidemiol 1986; 124:17-27.

9. Rockett HR, Berkey CS, Colditz GA. Evaluation of dietary assessment tools in adolescents. Curr Opin Clin Nutr Metab Care 2003; 6:557-62.

10. Cullen KW, Watson K, Zakeri I. Relative reliability and validity of the Block Kids Questionnaire among youth aged 10 to 17 years. J Am Diet Assoc 2008; 108:862-6.

11. Goodwin RA, Brulé D, Junkins EA, Dubois S, BeerBort S. Development of a food and activity record and a portion-size model booklet for use by 6 to 17 year olds: a review of focus group testing. J Am Diet Assoc 2001; 101:926-8.

12. Cade J, Thompson R, Burley V, Warm D. Development, validation and utilization of food-frequency questionnaires: review. Public Health Nutr 2002; 5:567-87. 
13. Egashira EM, Aquino RC, Philippi ST. Técnicas e métodos para a avaliação do consumo alimentar. In: Tirapegui J, Ribeiro SML, organizadores. Avaliação nutricional: teoria e prática. Rio de Janeiro: Editora Guanabara Koogan; 2009. p. 13-23.

14. Block G, Dresser CM, Hartman AM, Caroll MD. Nutrient sources in the American diet: quantitative data from the NHANES II survey. II. Macronutrients and fats. Am J Epidemiol 1985; 122:27-40.

15. Philippi ST, Aquino RC, Leal GVS. Necessidades e recomendações nutricionais. In: Palma D, Oliveira FLC, Escrivão MAMS, organizadores. Guia da nutrição na infância e na adolescência. Barueri: Edições Manole; 2009. p. 55-67.

16. Araújo MC, Ferreira DM, Pereira RA. Reprodutibilidade de questionário semiquantitativo de freqüência alimentar elaborado para adolescentes da Região Metropolitana do Rio de Janeiro, Brasil. Cad Saúde Pública 2008; 24:2775-86.

17. Voci SM, Enes CC, Slater B. Validação do Questionário de Freqüência Alimentar para Adolescentes (QFAA) por grupos de alimentos em uma população de escolares. Rev Bras Epidemiol 2008; 11:561-72.

18. Serra-Majem L, Pfrimer K, Doreste-Alonso J, RibasBarba L, Sánchez-Villegas A, Ortiz-Andrellucchi A, et al. Dietary assessment methods for intakes of iron, calcium, selenium, zinc and iodine. Br J Nutr 2009; 102 Suppl 1:S38-55.

19. Deschamps V, Lauzon-Guillain B, Lafay L, Borys J, Charles MA, Romon M. Reproducibility and relative validity of a food-frequency questionnaire among French adults and adolescents. Eur J Clin Nutr 2009; 63:282-91.

20. Fornés NS, Stringhini MLF, Elias BM. Reproducibility and validity of a food-frequency questionnaire for use among low-income Brazilian workers. Public Health Nutr 2003; 6:821-7.

21. Marks GC, Hughes MC, Van Der Pols JC. Relative Validity of food intake estimates using a food frequency questionnaire is associated with sex, age, and other personal characteristics. J Nutr 2006; 136:459-65.

22. Malekshah AF, Kimiagar M, Saadatian-Elahi M, Pourshams A, Nouraie M, Goglani G, et al. Validity and reliability of a new food frequency questionnaire compared to $24 \mathrm{~h}$ recalls and biochemical measurements: pilot phase of Golestan cohort study of esophageal cancer. Eur J Clin Nutr 2006; 60:971-7.

23. Millen AE, Midthune D, Thompson FE, Kipnis V, Subar AF. The National Cancer Institute Diet History Questionnaire: validation of pyramid food servings. Am J Epidemiol 2006; 163:279-88.
24. Spencer EH, Elon LK, Hertzberg VS, Stein AD, Frank E. Validation of a Brief Diet Survey Tool among medical students. J Am Diet Assoc 2005; 105:802-6.

25. Pisani P, Faggiano F, Krogh V, Palli D, Vineis P, Benino F. Relative validity and reproducibility of a food frequency dietary questionnaire for use in the Italian EPIC centres. Int J Epidemiol 1997; 26 Suppl 1:S152-60.

26. Hong S, Choi Y, Lee H, Kim S, Oe Y, Lee S, et al. Development and validation of a semi-quantitative food frequency questionnaire to assess diets of Korean type 2 diabetic patients. Korean Diabetes J 2010; 34:32-9.

27. Assis MAA, Guimarães D, Calvo MCM, Barros MVG, Kupek E. Reprodutibilidade e validade de questionário de consumo alimentar para escolares. Rev Saúde Pública 2007; 41:54-7.

28. Masson LF, McNeill G, Tomany JO, Simpson JA, Peace HS, Wei L, et al. Statistical approaches for assessing the relative validity of a semi-quantitative food frequency questionnaire: use of correlation coefficients and the kappa statistic. Public Health Nutr 2003; 6:313-21.

29. Marchioni DM, Voci SM, Lima FEL, Fisberg RM, Slater B. Reproducibility of a food frequency questionnaire for adolescents. Cad Saúde Pública 2007; 23:2187-96.

30. Burley V, Cade J. Consensus document on the development, validation and utilization of food frequency questionnaires. In: The Fourth International Conference on Dietary Assessment Methods. Tucson: University of Arizona's Prevention Center; 2000. p. 17-20.

31. Speck BJ, Bradley CB, Harrell JS, Belyea MJ. A food frequency questionnaire for youth: psychometric analysis and summary of eating habits in adolescents. J Adolesc Health 2001; 28:16-25.

32. Vereecken CA, Maes L. A Belgian study on the reliability and relative validity of Health Behavior in School-Aged Children Food-Frequency Questionnaire. Public Health Nutr 2003; 6:581-8.

33. Albano RD, Souza SB. Ingestão de energia e nutrientes por adolescentes de uma escola pública. J Pediatr (Rio J.) 2001; 77:512-6.

34. Lerner BR, Lei DLM, Chaves SP, Freire RD. O cálcio consumido por adolescentes de escolas públicas de Osasco, São Paulo. Rev Nutr 2000; 13:57-63.

35. Toral N, Slater B, Cintra IP, Fisberg M. Adolescent eating behavior regarding fruit and vegetable intakes. Rev Nutr 2006; 19:331-40.

Submitted on 18/Apr/2012

Final version resubmitted on 19/Feb/2013

Approved on 24/Apr/2013 